FACTA UNIVERSITATIS

Series: Physical Education and Sport, Vol. 17, No 3, 2019, pp. 463 - 477

https://doi.org/10.22190/FUPES190907041M

Research article

\title{
THE RELATIONSHIP BETWEEN TECHNICAL AND TACTICAL ELEMENTS OF DIRECT POINTS WITH REGARD TO THE QUALIFICATIONS FOR THE 2018 VOLLEYBALL WOMEN'S WORLD CHAMPIONSHIP
}

\author{
UDC 796.325[2018]
}

\section{Zoran Momčilović ${ }^{1}$, Srđan Marković ${ }^{2}$, Aleksandar Vićentijević ${ }^{3}$, Goran Nešić $^{4}$, Dragana Bogavac ${ }^{5}$, Tatjana Milosavljević Đukić ${ }^{1}$}

\author{
${ }^{1}$ Pedagogical Faculty, University of Niš, Vranje, Serbia \\ ${ }^{2}$ Faculty of Physical Education and Sports Management, Singidunum University, \\ Belgrade, Serbia \\ ${ }^{3}$ The University of Belgrade Sports Association, Belgrade, Serbia \\ ${ }^{4}$ Faculty of Sport and Physical Education, University of Belgrade, Belgrade, Serbia \\ ${ }^{5}$ Teacher Education Faculty, University of Belgrade, Belgrade, Serbia
}

\begin{abstract}
The goal of this paper is to analyse the relationships and differences among volleyball teams, participants of the 2018 World Cup in Japan, divided into three categories by their final standings ( $1^{\text {st }}$ to $4^{\text {th }}$ place, $5^{\text {th }}$ to $8^{\text {th }}$ place and others), based on the elements of situation-based efficiency. For the purposes of this paper, information from the official match reports ( $p 2$ report) related to the way of winning points in the match was used, and these data were analysed using the program Volleyball Information System (VIS). The data obtained were analysed in relation to the team category and the outcome of the match. The data were obtained using descriptive and comparative statistical procedures. The survey sample includes all the women's volleyball championship games played in Japan in 2018. Based on the final standings, the teams were divided into three groups: 1) the teams who reached the $3^{\text {rd }}$ stage of the tournament (6 teams, from $1^{\text {st }}$ to $6^{\text {th }}$ place); 2$)$ the teams that finished the competition in phase 2 (10 national teams, ranking $7^{\text {th }}$ to $16^{\text {th }}$ ); 3 ) national teams that finished the competition in phase 1 ( 8 national teams, ranking $17^{\text {th }}$ to $24^{\text {th }}$ ). The results obtained indicate that the teams had an equally good performance of the block and serve game elements; statistically these were not significant for the match outcome, but they rather serve as an aid for the overall game and for the final outcome of the match. The results of this research also highlight the spike as the key element affecting the positive end result of the match. It is important to emphasize that the opponent errors are a factor that depends exclusively on the opponent, but they also determine the overall score of the winning team.
\end{abstract}

Key words: Categories, Efficiency, Technical and Tactical Elements, Girls, Standings

Received September 07, 2019/ Accepted December 24, 2019

Corresponding author: Tatjana Milosavljević Đukić

Pedagogical Faculty, University of Niš, Vranje, Partizanska 14, 17500 Vranje, Serbia

Phone: +381 17431960 •E-mail: tatjanamdj@pfvr.ni.ac.rs 


\section{INTRODUCTION}

Outwitting the opponent is a dominant volleyball tactic, decisions are made in the present moment, it is a very demanding sport, because out of a large number of options, the right decision should be made at that very moment, which makes this sports game interesting.

Science and papers that deal with the development of sports games are increasingly trying to find the trends that influence the development of volleyball, as well as to separate the group of technical and tactical elements which are important for scoring points and which affect the final standings of teams in the championships.

Science is required for the further development of volleyball and it is necessary that significant issues related to the theory and practice of contemporary volleyball are explored, and that the lessons learned are incorporated into the processes of initial and stage selection, as well as into the technological modernization of the volleyball teams' preparation process, and that the careers of young volleyball talents are subsequently directed. Significant differences among the volleyball teams, depending on their varying degrees of quality, require that special attention be paid to top teams and their technical and tactical activity when competing with teams of similar or the same quality (Brezić, 2006). Modern volleyball, as sport in general, is getting more and more directly related to science (Tomić \& Nemec, 2002).

Each sports game has its own specifics and parameters that should be tracked. The same statistics and tracking cannot be applied to all sports games, which is why the use of special techniques is required based on the specific sport.

Volleball activities include the following components:

- A spatial component: jumps, jump to attack, jump to block, jump to lift the ball for attack, jump to serve, falls (roll, roll dive), footwork (hop step, cross-over step), running, ball strikes i.e., to spike, to serve (Nejić, Stanković, Nejić, \& Stojadinović, 2016);

- A temporal component: active game time, passive game time (during the sets, between the sets), total match time, as well as the total match time plus the time required for warm-ups;

- A technical and tactical component, which includes the technical and tactical elements of volleyball.

The technical and tactical component of the volleyball game can be divided into two phases: "Phase 1" includes the game elements: serve, block, defense, lift the ball to attack, attack. This phase of the game refers to the team which serves. "Phase 2" includes the following game elements: serve receive, lift the ball to attack, attack. "Phase 2" refers to the opposite team that has to receive a serve (Milosavljević, 2015).

Based primarily on his own coaching experience, Velasco (1998) believes that the volleyball game structure consists of a constant switch between attack and defence, that is, of a transition from one action to another and vice versa.

The volleyball game components relating to situation-based efficiency are those elements which help the team to score, which can be achieved from attack and counterattack, that is, by using: a serve, spike, block. The attack implies that the team scored a point after receiving the serve, while the counterattack implies the attack that occurred after the successful defence and includes all those balls that were passed to the opposing team. The counterattack allows the team to quickly switch to the attack mode and to try to win points in different ways after 
the successful defence. The spike is the most dominant element of a volleyball game which brings points. Other game elements also play a significant role in the game and provide tactical advantage over the opponents, but in total the team scores the most points by spiking. It is certainly interesting to find out which of the five types of team preparation (technical, physical, psychological, tactical and theoretical) is crucial for the team efficiency, that is, how each of these determine the final result (Nešić, 2006).

The goal of this paper is to analyse the relationships and differences among the volleyball teams, participants of the 2018 World Cup in Japan, divided into three categories by their final standings ( $1^{\text {st }}$ to $4^{\text {th }}$ place, $5^{\text {th }}$ to $8^{\text {th }}$ place and others), based on the elements of situationbased efficiency.

\section{METHODS}

The issue that this research is dealing with is the current competitive structure of the activities of the best female senior volleyball teams in the world. The subject of this research is the structure (the components) of the technical and tactical volleyball actions; this structure is extremely complex, that is, it contains the components from which a direct point is scored (components of situation-based precision), and it is of great importance.

We assumed that the way a team scores points depends on the team category and the outcome of the match. Assumptions are given as follows:

1. The number of points scored with a block (per set and in relation to the total number of attempts) depends on the team category and the outcome of the match;

2. The number of points scored with a serve (per set and in relation to the total number of attempts) depends on the team category and the outcome of the match;

3. The number of points scored with a spike (per set and in relation to the total number of attempts) depends on the team category and the outcome of the match;

4. The number of points scored after the opponent's error depends on the team category and the outcome of the match.

The sample used in this paper is made up of all the women's volleyball championship matches played in Japan in 2018. Twenty-four (24) teams participated in the championship, and played a total of 103 matches, so the total sample consists of 206 game outcomes (each match contains 2 teams' outcomes). Based on the final standings, the teams were divided into three groups: 1 ) the teams who reached the $3^{\text {rd }}$ stage of the tournament (6 teams, from $1^{\text {st }}$ to $6^{\text {th }}$ place); 2) the teams that finished the competition in phase 2 (10 national teams, ranking $7^{\text {th }}$ to $\left.16^{\text {th }}\right) ; 3$ ) national teams that finished the competition in phase 1 (8 national teams, ranking $17^{\text {th }}$ to $24^{\text {th }}$ ).

Table 1 shows the number of matches and the outcome of the matches played by teams from each category.

Table 1 The number and the outcome of matches by team category

\begin{tabular}{ccccc}
\hline Category & Number of teams & Total Number of matches & Number of wins & Number of losses \\
\hline 1 & 6 & 75 & 56 & 19 \\
2 & 10 & 90 & 42 & 48 \\
3 & 8 & 41 & 5 & 36 \\
\hline
\end{tabular}


The Volleyball Information System (VIS), the official software of the International Volleyball Federation (Federation Internationale de Volleyball-FIVB, n.d.) was used to collect and analyze the data. This system was created in order to support the organization of volleyball competitions and to inform the audience on the volleyball match details.

It consists of the central database where all the data are stored, and a series of web portals which the authorized users use to enter data into the system; these web portals then allow the audience to access and look at that data. For the purposes of this paper, information from the official match reports ( $\mathrm{p} 2$ report) related to the way of winning points in the match was also used:

- Opponent's error (ERROR);

- The number of points scored with a serve per set (SERV);

- The number of points scored with a serve in relation to the total number of serves (\% SERV);

- The number of points scored with a block per set (BLOCK);

- The number of points scored with a block in relation to the total number of block attempts (\% BLOCK);

- The number of points scored with a spike per set (SPIKE);

- The number of points scored with spike in relation to the total number of spike attempts (\% SPIKE).

The data obtained were analyzed in relation to the team category (CAT, category 1 3 , defined in the previous section) and in relation to the match outcome (OUTCOME), that is, whether the match ended in a win or a loss. Survey data were analysed using descriptive and comparative statistics. Descriptive indicators are presented using mean values (MV) and standard deviation (SD). The results are shown in tables and graphs. The following discrimination tests were applied within comparative statistics:

- The Two-Way Analysis of Variance (ANOVA) was used to evaluate the influence of the interaction between the "team category" factor (1,2 or 3$)$ and the "match outcome" factor (win, loss) on the variables examined;

- The One-Way Analysis of Variance (ANOVA) was used to evaluate the difference between the "team categories" when the "outcome of the match" factor is equal (separately for the losses, and separately for the wins);

- The Student's t-test was used for the independent samples with a correction for different sample sizes in order to identify the differences in the way points were scored within a certain team category in the case of different "match outcomes" (win, loss).

\section{RESULTS}

Tables 2-5 show the results of descriptive statistics of the examined variables for the different team categories, especially in the games in which the teams won or were defeated, while the graphs 1-7 show the results of the two-way analysis of variance of the examined variables for the CAT and OUTCOME factors.

Table 2 shows the descriptive statistics results for the SERV and \% SERV variables. Minimal differences between the categories were observed as well as the fact that category 1 (which includes the best teams) has the worst results for both variables with 
regard to the wins, while the opposite is the case regarding the losses when it comes to the variable SERV, and the results were equal from the aspect of the \% SERV variable.

Table 2 Descriptive statistics indicators of points scored with a serve (per set and in relation to the total number of serves)

\begin{tabular}{ccccc}
\hline Team category & \multicolumn{2}{c}{ Serves per set (number of points ) } & \multicolumn{2}{c}{ Serve (\%) } \\
\cline { 2 - 5 } & Wins & Losses & Wins & Losses \\
\hline 1 & $1.67 \pm 0.93$ & $1.08 \pm 0.55$ & $6.96 \pm 3.80$ & $5.21 \pm 2.62$ \\
2 & $1.85 \pm 0.94$ & $1.08 \pm 0.66$ & $7.69 \pm 3.85$ & $5.36 \pm 3.10$ \\
3 & $2.18 \pm 1.01$ & $1.01 \pm 0.68$ & $8.81 \pm 4.31$ & $5.51 \pm 3.35$ \\
\hline
\end{tabular}

The results of the two-way ANOVA for the variable SERV indicate that the factors CAT and OUTCOME did not significantly affect the results $(\mathrm{F}=.876 ; \mathrm{p}>.05)$. When the results were observed only from the aspect of the OUTCOME variable, there were significant differences between the matches won or lost by a team $(p<.05)$, while there were no significant differences between the individual categories with regard to the CAT variable ( $p>.05)$. From the aspect of the sub-samples of the team categories, a significant difference was observed depending on the OUTCOME variable in all categories $(\mathrm{p}<.05)$, while no differences were observed between the categories regardless of whether the teams win or lose the match (p>.05; Graph 1).

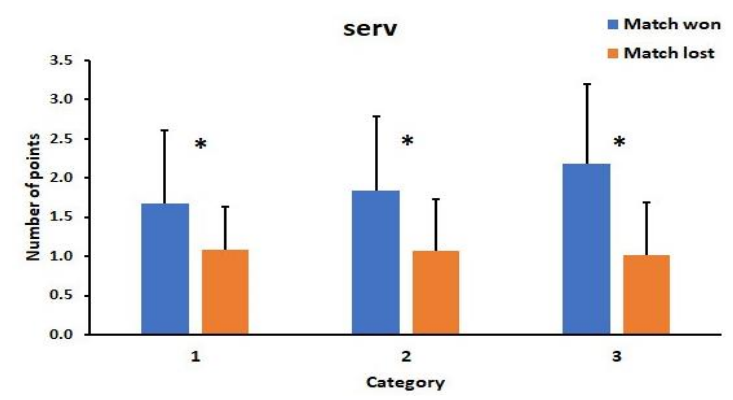

Graph 1 Mean values and standard deviation for the SERV variable with differences between certain groups

Legend: * significant difference in relation to the OUTCOME variable

The Two-Way ANOVA results for the \% SERV variable indicate that the interaction between the CAT and OUTCOME factors does not affect the results significantly $(\mathrm{F}=.348 ; \mathrm{p}>.05)$. When the results were observed only from the aspect of the OUTCOME variable, there were significant differences between the matches won or lost by a team $(p<.05)$. From the aspect of the sub-samples of the team categories, a significant difference was observed depending on the OUTCOME variable in all categories $(\mathrm{p}<.05)$, while no differences were observed between the categories regardless of whether the teams win or lose the match ( $>$ >.05; Graph 2). 


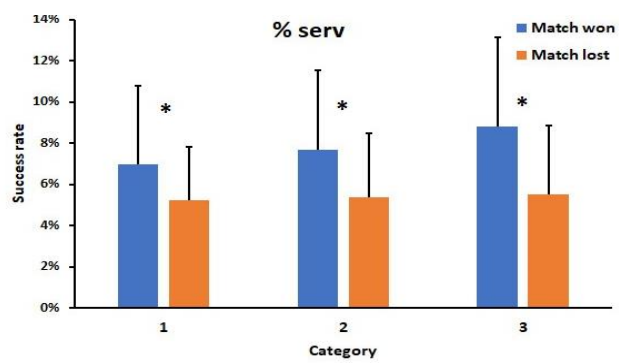

Graph 2 Mean values and standard deviation for the \% SERV variable with differences between certain groups

Legend: * significant difference in relation to the OUTCOME variable

Table 3 shows the descriptive statistics results for the variables SPIKE and \% SPIKE. There were no differences in the win results from the aspect of both variables, while a difference was actually observed in the loss results regarding the SPIKE variable.

Table 3 Descriptive statistics indicators of points scored with a spike (per set and in relation to the total number of spike attempts)

\begin{tabular}{ccccc}
\hline \multirow{2}{*}{ Team category } & \multicolumn{2}{c}{ Spikes per set (number of points) } & \multicolumn{2}{c}{ Spike (\%) } \\
\cline { 2 - 5 } & Wins & Losses & Wins & Losses \\
\hline 1 & $14.63 \pm 1.66$ & $12.57 \pm 1.91$ & $49.24 \pm 7.07$ & $37.94 \pm 4.82$ \\
2 & $14.16 \pm 2.39$ & $12.40 \pm 2.78$ & $48.51 \pm 8.31$ & $38.67 \pm 7.04$ \\
3 & $15.22 \pm 1.55$ & $10.15 \pm 2.71$ & $46.25 \pm 3.27$ & $35.24 \pm 7.29$ \\
\hline
\end{tabular}

The Two-Way ANOVA results for the SPIKE variable indicate that the interaction between the CAT and OUTCOME factors affects the results significantly $(\mathrm{F}=3.776 ; \mathrm{p}<.05)$. When the results were observed only from the aspect of the OUTCOME variable, there were significant differences between the matches won or lost by a team, while there were no significant differences observed at the level of the CAT variable. From the aspect of the sub-samples of the team categories, a significant difference was observed depending on the OUTCOME variable in all the three categories, while the differences between the categories were observed only in the games lost by the teams ( $\mathrm{p}<.05$; Graph 3$)$.

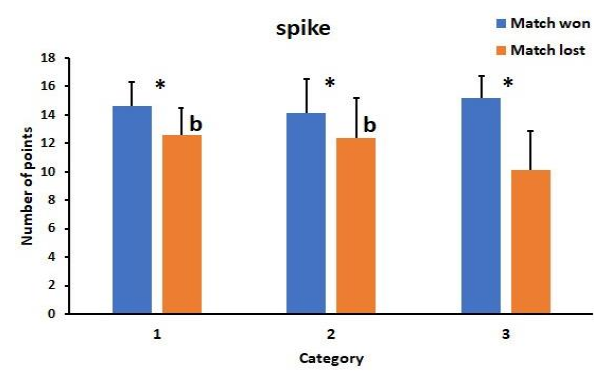

Graph 3 Mean values and standard deviation for the SPIKE variable with differences between certain groups

Legend: * significant difference in relation to the OUTCOME variable; $\mathrm{b}$ - significant difference in relation to the category 3 
The two-way ANOVA results for the \% SPIKE variable indicate that the interaction between the CAT and OUTCOME factors does not affect the results significantly $(\mathrm{F}=.198 ; \mathrm{p}>.05)$. When the results were observed only from the aspect of the OUTCOME variable, there were significant differences between the matches won or lost by a team, while there were no significant differences observed at the level of the CAT variable. From the aspect of the sub-samples of the team categories, a significant difference was observed depending on the OUTCOME variable in all the categories $(p<.05)$, while no differences were observed between the categories regardless of whether the teams win or lose the match ( $\mathrm{p}>.05$; Graph 4).

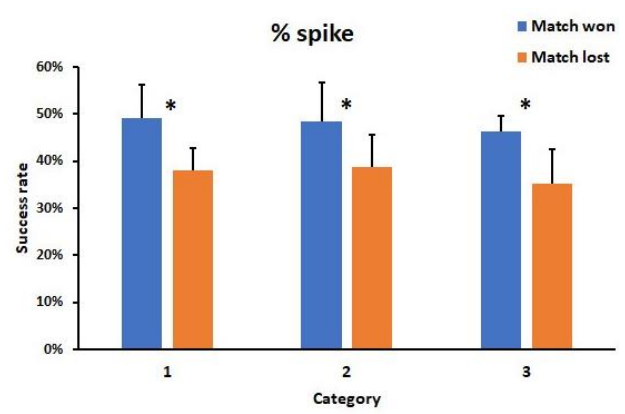

Graph 4 Mean values and standard deviation for the \% SPIKE variable with differences between certain groups

Legend: * significant difference in relation to the OUTCOME variable

Table 4 shows the descriptive statistics results for the variables BLOCK and \% BLOCK. There were no significant differences observed with regard to any variable in question.

Table 4 Descriptive statistics indicators of points scored with a block (per set and in relation to the total number of block attempts)

\begin{tabular}{ccccc}
\hline Team & \multicolumn{2}{c}{ Blocks per set (number of points) } & \multicolumn{2}{c}{ Block (\%) } \\
\cline { 2 - 5 } category & Wins & Losses & Wins & Losses \\
\hline 1 & $2.74 \pm 0.88$ & $1.66 \pm 0.94$ & $21.71 \pm 6.93$ & $14.20 \pm 6.55$ \\
2 & $2.98 \pm 1.56$ & $1.63 \pm 0.82$ & $23.96 \pm 8.58$ & $15.88 \pm 7.89$ \\
3 & $2.83 \pm 1.24$ & $1.97 \pm 1.85$ & $25.83 \pm 7.79$ & $17.41 \pm 8.61$ \\
\hline
\end{tabular}

The two-way ANOVA results for the BLOCK variable indicate that the interaction between the CAT and OUTCOME factors does not affect the results significantly $(\mathrm{F}=.395$; $\mathrm{p}>.05)$. When the results were observed only from the aspect of the OUTCOME variable, there were significant differences between the matches won or lost by a team, while there were no significant differences observed at the level of the CAT variable. From the aspect of the sub-samples of the team categories, a significant difference was observed depending on the OUTCOME variable in the categories 1 and $2(\mathrm{p}<.05)$, while no differences were observed between the categories regardless of the match outcome ( $p>.05$; Graph 5). 


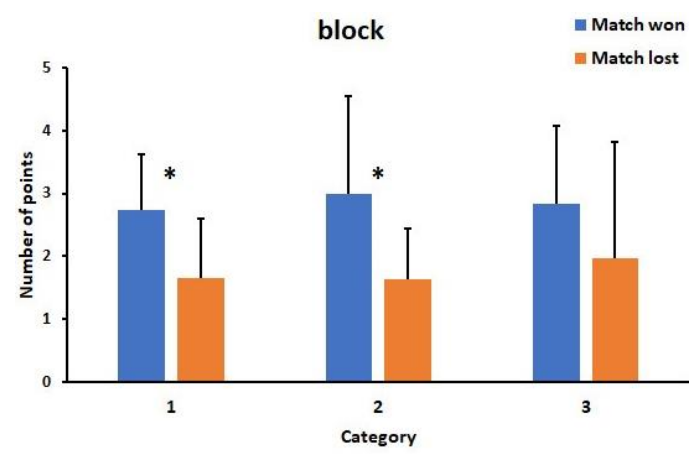

Graph 5 Mean values and standard deviation for the BLOCK variable with differences between certain groups

Legend: * significant difference in relation to the OUTCOME variable

The two-way ANOVA results for the \% BLOCK variable indicate that the interaction between the CAT and OUTCOME factors does not affect the results significantly $(\mathrm{F}=.033$; $p>.05)$. When the results were observed only from the aspect of the OUTCOME variable, there were significant differences between the matches won or lost by a team, while there were no significant differences observed at the level of the CAT variable. From the aspect of the sub-samples of the team categories, a significant difference was observed depending on the OUTCOME variable in all the categories $(\mathrm{p}<.05)$, while no differences were observed between the categories regardless of the match outcome ( $p>05$; Graph 6).

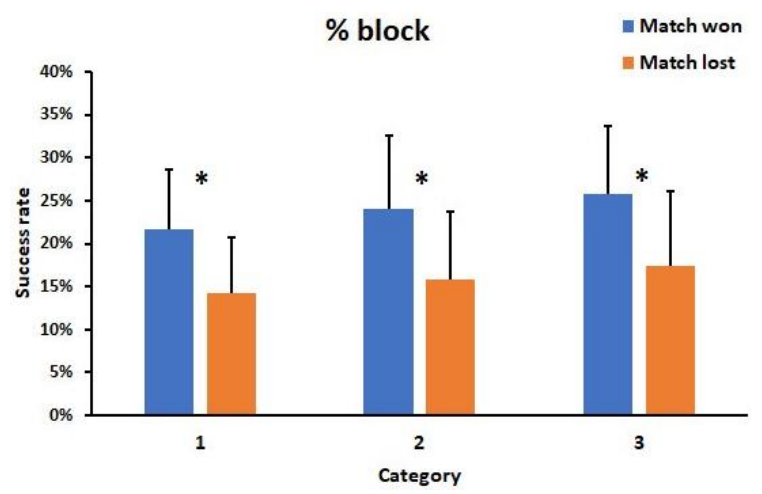

Graph 6 Mean values and standard deviation for the \% BLOCK variable with differences between certain groups

Legend: * significant difference in relation to the OUTCOME variable

Table 5 shows the descriptive statistics results for the ERROR variable. There were differences observed between the categories only with regard to the losses. 
Table 5 Descriptive statistics indicators of points scored after the opponent's error

\begin{tabular}{|c|c|c|}
\hline \multirow[t]{2}{*}{ Team category } & \multicolumn{2}{|c|}{ Opponent's errors per set (number of points) } \\
\hline & Wins & Losses \\
\hline 1 & $5.34 \pm 1.42$ & $5.22 \pm 1.29$ \\
\hline 2 & $5.42 \pm 1.21$ & $4.51 \pm 1.47$ \\
\hline 3 & $5.52 \pm 1.26$ & $4.20 \pm 1.41$ \\
\hline
\end{tabular}

The two-way ANOVA results for the ERROR variable indicate that the interaction between the CAT and OUTCOME factors does not affect the results significantly $(\mathrm{F}=1.949 ; \mathrm{p}>.05)$. From the aspect of the sub-samples of the team categories, a significant difference was observed depending on the OUTCOME variable in categories 2 and 3 $(\mathrm{p}<.05)$; significant differences were also observed between categories 1 and 3 in the matches lost ( $\mathrm{p}<.05 ;$ Graph 7).

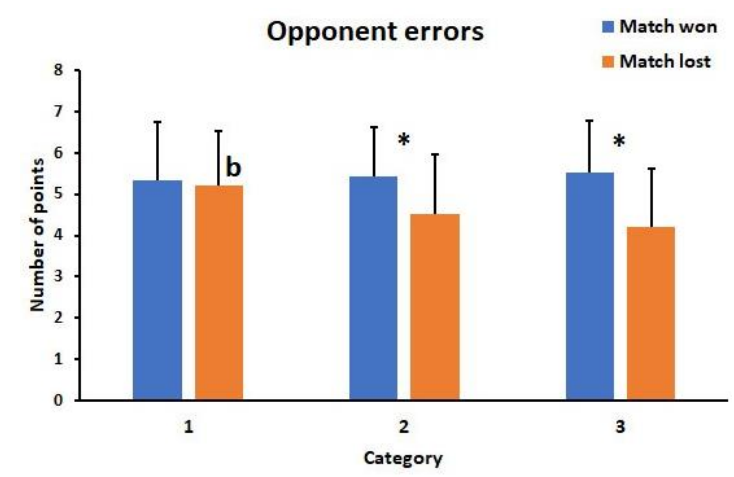

Graph 7 Mean values and standard deviation for the ERROR variable with differences between certain groups

Legend: * significant difference in relation to the OUTCOME variable; $\mathrm{b}$ - significant difference in relation to the category 3

\section{DISCUSSION}

The number of points scored with a serve does not differ significantly in relation to the interaction between the team category and the match outcome factors. Based on the results we can see that the serve has no significant effect and does not directly affect if a team wins (based on the statistics of direct points scored during the match). Serve errors are also a very significant factor when it comes to the total number of points during a match. This analysis increases the importance of developing a serving strategy (Valladares, García-Tormo, \& João, 2016). The serve is actually the first contact with the ball, and also the first opportunity to score a point, but a good serve can also prevent the opponent from performing the ideal attack which then prevents the team that served to organize the defence strategy on time. Based on the statistical results, we can conclude that coaches should focus on serve performance in order to score more direct points from this volleyball component and increase the possibility of winning more points than the opponent, thus having a greater chance of winning. We have to emphasize that the serve 
parameter was used for the purposes of this paper, as well as the number of points scored using this game component; however, we have not analysed serving effectiveness as a volleyball game element that prevents the opponent from effectively organizing the attack and scoring a point. The statistical results of the opponent's poor serve reception due to the well-executed serve could allow us to see that serve is important not only as a volleyball technique that is used to score points directly, but it can also be used to prevent the opponent from organizing a successful and efficient attack. These assumptions have been confirmed by many authors who have dealt with this topic. More efficient serves enable the team that serves to organize the defense more easily and efficiently due to the poor and scattered serve reception by the opposing team and their inability to attack at the right pace (Buscà, Moras, Peña, \& Rodríguez-Jiménez, 2013). Attack and serve efficiency are the elements used most frequently to define technical and tactical efficiency, since they are the technical and tactical elements that begin and end the attack phase which the efficiency in scoring points depends on, and which are crucial for the final outcome of a set and match (Nešić, 2006). The number of direct points scored with serve does not differ significantly in relation to the team category which means that the teams have the same number of points won in total. The main difference is reflected in the fact if a team lost or won the game, and based on these parameters, there are obvious differences among the teams in relation to team categories. There was a slight difference in category 1 teams matches depending on whether they won or lost the game, while in categories 2 and 3 there was a significant difference in the matches won compared to the matches lost. Therefore, stability was observed in category 1 teams regarding the serves, regardless of whether they lost or won, while in categories 2 and 3, the serve clearly affected the match outcome, because in the matches they won, the teams had a similar or the same percentage as the teams from category 1 , while in the matches they lost, the teams had a very poor performance of the serve which caused a small number of points to be scored. Therefore, the number of points scored with serve varies depending on the outcome of the match.

Serving efficiency also determines the outcome of the match, since based on the results obtained, it was evident that the teams that won a match had a good serve efficiency, while the teams that lost a game had a bad serve efficiency. This clearly indicates that psychological factors also affect the efficiency of certain volleyball techniques, in this case of the serve. In addition to other volleyball game elements, serving efficiency also significantly determines the positive match outcome, and based on the results obtained this has been proven to be correct. Using a comparative analysis of serve efficiency coefficients, it was determined that there was a statistically significant difference between the two groups of teams. On average, the group of less successful teams had a serve efficiency of $33.67 \%$, while the group of successful teams had a serve efficiency of $41.56 \%$. According to the results of actual research, the serve is an extremely significant technical and tactical game tool (Majstorović, 2015).

The percentage of points scored with a serve (in relation to the total number of serves) does not differ significantly depending on the interaction between the team category and match outcome factors, as we have seen that all teams have approximately the same positive percentage of points scored with a serve in the matches they won, as well as approximately the same negative efficiency in the matches that they lost, which has been proven for the team categories, while a very slight difference was noticed only depending on the match outcome. 
The number of points scored from attack attempts varies significantly depending on the interaction between the team category and match outcome factors. The spike stands out as a significant volleyball technique that directly influences the final outcome of a match. Spike efficiency is crucial to winning points. This claim is also confirmed by Nešić (2006) when saying that the group of less successful teams on average achieves an attack efficiency of $52.17 \%$, while successful teams achieve $59.04 \%$. The attack efficiency is crucial to winning points, regardless of whether the team's efficiency in other technical and tactical elements is high. An effective attack allows the team to compensate for any deficiencies in serve reception or lifting the ball for attack, so it is expected that this element is more crucial in determining the match result than serve reception and lifting the ball for attack (Majstorović, 2015).

Coaches pay the most attention to attack efficiency and the impact of reducing errors, and the statistical results have proven these elements to be significant for the final standings in the competition. Such results have been confirmed and supported by previous studies, which also claim that the attack is a significant technical and tactical element which determines the final championship outcome (Patsiaouras, Moustakidis, Charitonidis, \& Kokaridas, 2011).

The number of points scored from attack attempts in category 1, 2 and 3 teams matches differ significantly depending on whether they won or lost the game. The conclusion is that the teams that had effective attacks eventually won the match, while the field attack using the spike technique was of crucial importance for the teams to win the game. These results are further supported by the fact that the teams which lost the games also had a negative percentage of points scored from attack attempts. The number of points scored from attack attempts differ significantly between the category 1 and 2 teams, 1 and 3 teams, 2 and 3 teams, in those cases when the teams lost the match. As we have already said, good attack efficiency is crucial for the victory of the teams, while poor attack performance results in a loss of a match. If excessive attack errors are made, or the team is unable to organize the attack and transfers the ball into the opponent's field, then the opponent is given the chance to score a point with a counter-attack.

The number of points scored with an attack varies depending on the match outcome, which means that the effectiveness of the team depends on the performance of this volleyball game element. The teams that excel in an attack are more likely to win the match.

The percentage of points scored from attack attempts (in relation to the total number of attacks) does not vary significantly depending on the interaction between the team category and match outcome factors. The percentage of points scored with a spike (in relation to the total number of attacks) differ significantly among all team categories depending on whether the team won or lost the game. The teams that made it to the finals of the competition had a high efficiency of points scored in relation to the number of attacks performed, so a significant difference was observed depending on the team category. This further explains their final standings in the competition with regard to the positive results obtained depending on the match outcome.

Many authors have studied the structure of the volleyball game (Železnak, 2004; Cabrini, 1995; Bosco, 1994; Fontani, 1994; Cardinal, 1993; Viitasalo, 1991; Ivojlov, 1984) and all have come to the conclusion that elements crucial for an effective game are the volleyball movements, that is, jumps, ball hits, fast - agile movement in the field, and anticipation which comes with experience. 
The number of points scored with a block does not vary significantly depending on the interaction between the team category and match outcome factors. Block positioning is a complex process, it is influenced by a large number of situation-based effects that block players have to notice, resolve and then take an adequate position in a timely manner. Many authors have investigated the difference between a single and double block, and the obtained results have clearly shown that a single block is less efficient than a double block (Meskuita \& Cesar, 2007; Afonso, Meskuita, \& Palao, 2005; Palao, Santos, \& Urena 2004). A double block requires players to be faster and to quickly switch into the defence mode against the attacking opponent. The statistical results only include block efficiency when a direct point is scored. However, the blocking technique has one more role to play: an effective block is not only when the team scores a direct point, but also when it allows the team to take a good defence position by defending a certain part of the pitch and making it easier for the defence players. Therefore, the results obtained show that there is no significant difference in winning direct points with regard to the points won with a block, because the number of points scored in all three categories is approximately the same.

The number of points scored with a block differs significantly between the category 1 and 2 teams depending on whether they won or lost the game. This parameter shows us that the block has a positive impact on the team. The team that had more effective blocks eventually won the match, and according to the statistical results the team that had a small number of points scored with a block as a consequence lost the game.

The number of points scored with a block does not differ significantly depending on the team category. If all the teams are compared, regardless of the competition phase they reached, the results show that their block efficiency did not affect their final results. So, all teams in the championship had about the same percentage of successful blocks in relation to the number of block attempts. The study conducted by Majstorović (2015) by using the comparative analysis of the block efficiency coefficient, found a statistically significant difference between the two groups of teams. The group of less successful teams on average had a block efficiency of $51.94 \%$, while the successful teams' block efficiency was $56.46 \%$. The same is confirmed by Nešić (2006) - the group of less successful national teams had an average block efficiency of $49.71 \%$, while the successful teams' block efficiency was $53.25 \%$.

The number of points scored with a block differs significantly depending on the match outcome, which means that there is no difference between the teams with regard to block effectiveness, meaning that everyone's block technique is equally good or bad.

However, block effectiveness affects the attitude of the team and their game (therefore, the match outcome as well), because when the teams lost the game, they had a poor block performance, and when they won, they had a high number of points scored with a block. Thus, the results obtained prove that block efficiency differs depending on whether a match was won or lost.

This result confirms and supports the claims of other prominent volleyball experts who said that the block is a significant technical and tactical element which the effectiveness of winning or losing a game or success in a tournament depends on (Gajić, 2005; Janković \& Sabljak, 2004; Železnak, 2004; Tomić \& Nemec, 2002).

Based on the obtained results, the percentage of points scored with a block (in relation to the total number of blocks) does not differ significantly depending on the interaction between the team category and the match outcome factors, and it does not 
differ significantly depending on the team category. However, the differences were recorded in all team categories in the matches they won and lost which further shows that the differences depend on the final outcome of the match.

The opponent's errors do not significantly affect the outcome of the match, but they certainly affected the players' mental state and their further efficiency, depending on the moment at which those errors occurred. There were no significant differences observed among the team categories in the opponents' errors in the cases when the teams won. Moreover, a significant difference was observed between category 1 , and category 2 and 3 in situations where teams lost the match. Unlike categories 2 and 3, category 1 had the same number of errors regardless of the match outcome, which further indicates that category 1 teams did not lose games due to their errors, but because of their inefficiency or greater opponent efficiency. However, category 2 and 3 teams lost the matches due to the effectiveness of the opponents, but also due to their own big number of errors.

Studies on the level of risk that volleyball players take during further competition phases indicate that the risk of playing spikes increases, resulting in the increase in the number of failed spike attempts (Garcia-Tormo, Vaquera, \& Morante, 2015). In his presentations on the volleyball game structure, Velasco (1999) wrote about player errors during the game, which are a part of the modern volleyball (Rally Point Scoring-RPS). According to him, the structure and the number of errors are the key game elements that directly affect if a game is won or lost.

\section{CONCLUSIONS}

This paper tried to identify the differences between the teams which reached different stages of the competition in the way they scored points, based on the results of the 2018 volleyball women's world championship. The fact that these teams participated in the World Cup means that they are the best in the world in performing the technical volleyball elements, and morphologically and physically superior to all other teams. It was assumed that these teams have approximately equal efficiency in all game elements and that there are minimal differences among them. Based on the analysis of the data obtained at the end of the matches, it was observed that there were no major differences among the team categories with regard to serve and block efficiency; however, the spike was singled out as the crucial factor for the match outcome and final standings in the competition. Opponents' errors are a factor that depends directly on the opponents themselves, but it also affects the overall score of the winning team. The level the team is at depends on the way points are won and directly influences the outcome of the match. Therefore, the effectiveness of the team depends on the efficiency of all the volleyball game elements and the on the smallest number of errors possible since they also affect the end result (the main hypothesis partially confirmed).

Based on the data obtained in this paper, the spike is the crucial factor for the positive match outcome (assumption 3 confirmed), whereas all the other game elements are approximately the same in relation to all the teams in all the categories (assumptions 1 and 2 rejected). Therefore, the team becomes efficient by using the spike as the main game element to win points and by making as few mistakes as possible (assumption 4 confirmed). By analysing game activities, the coach identifies the weaknesses of the opponents and finds the right tactics to force them to make mistakes. 


\section{Z. MOMČILOVIĆ, S. MARKOVIĆ, A. VIĆENTIJEVIĆ, G. NEŠIĆ, D. BOGAVAC, T. MILOSAVLJEVIĆ ĐUKIĆ}

In order to perform a spike during a game, the ball must first go through other game elements such as a serve, serve reception, ball lifting, followed by the spike and the block by the opposing team. Therefore, according to the results obtained in this paper, the teams have equally good performance of the block and serve game elements, but statistically these game components are not significant for the match outcome in the form of points won; these are rather an aid in the implementation of other game elements. Therefore, in addition to practising the spike, coaches should have their team practice other game elements such as the block, serve, receiving and lifting in order to build a stable team that can perform stable attacks. Statistically, the teams did not score too many points with a block and serve which is why these game elements cannot be characterized as crucial to the match outcome. A well-executed serve causes the opposing team to have difficulty with their spike and with scoring a direct point, which allows the team to score a point with a properly positioned block. Therefore, if these two game elements are improved and become significantly more efficient, the match outcome will not solely depend on the spike performance efficiency, but it will rather be proportionally distributed to all the other game elements used to score points directly.

\section{REFERENCES}

Afonso, J., Mesquita, I., \& Palao, J. (2005). Relationship between the use of commit-block and the numbers of blockers and block effectiveness. International Journal of Performance Analysis in Sport, 5, 36-45.

Bosco, C. (1994). La preparazione fisica nella pallavolo femminile (Physical preparation in women's volleyball). Bollettino Tecnico Fipav, Roma. In Italian

Buscà, B., Moras, G., Peña, J., \& Rodríguez-Jiménez, S. (2013). The influence of serve characteristics on performance in men's and women's high-standard beach volleyball. Journal of Sport Sciences, 30(3), 269-276.

Brezić, G.S. (2016). Diskriminacioni kriterijumi uspešnosti u odbojkaškoj igri (Discriminatory criteria of success in volleyball). PhD Thesis. Belgrade: Faculty of Sport and Physical Education, University of Belgrade. In Serbian

Cardinal, C. (1993). Planification de l'entrainement en volley-ball (Planning volleyball training). Federation de Volley-ball du Quebec, Quebec. In French

Cabrini, P. (1995). Studi statistici sulla pallavolo maschile internazionale (Statistical studies on international men's volleyball). Bollettino tecnico Fipav, Firenze. In Italian

FIVB (n.d.). Volleyball. Retrieved on July 20, 2018 from the: http://www.fivb.com/en/volleyball/vis.

Fontani, G. (1994). Fisiologia della pallavolo (Physiology of volleyball). Insituto di Fisiologia Umana, Universita di Roma. In Italian

García-Tormo, J.V., Vaquera, A., \& Morante, J.C. (2015). Methodological proposal for the quantification and analysis of the level of risk assumed in volleyball service execution in female high-level competition, Journal of Physical Education and Sport, 15(1), 8.

Gajić, Z. (2005). Formiranje modela praćenja tehničko-taktičkih modela odbojkaške igre (Forming a model to monitor the technical and tactical models of volleyball game). Unpublished Master's Thesis. Belgrade: Faculty of Sports and Physical Education, Belgrade. In Serbian

Ivojlov, A. (1984). Takmičenja i trening sportista - Savremeni trening br. 3 (Athletes' competitions and training - Contemporary Training No. 3). The Yugoslav Institute for Physical Culture and Sports Medicine in Belgrade. In Serbian

Janković, V., \& Sabljak, M. (2004). Elementi tehnike odbojke i metodika (Elements of volleyball technique and methodology). Zagreb: Self-published by the Author.

Majstorović, N. et al. (2015). Analiza takmičarske aktivnosti u završnici "Winer stadtische” lige Srbije za odbojkaše u sezoni 2012/13 (Analysis of competitive activity in the finals of the "Wiener Stadtische" Serbia Volleyball League in the 2012/13 season). Fizička kultura, 69 (1), 51-58. In Serbian

Milosavljević, N. (2016). Tehničko-taktička struktura takmičarske aktivnosti odbojkašica (Technical and tactical structure of competitive volleyball activity). Graduate thesis. Belgrade: Faculty of Sport and Physical Education, University of Belgrade. In Serbian 
Mesquita, I., \& Cesar, B. (2007). Characterization of the opposite player's attack from the opposition block characteristics: An applied study in the Athens Olympic Games in female volleyball teams. International Journal of Performance Analysis in Sport, 7(2), 13-27.

Valladares, N., García-Tormo, J.V., \& João, P.V. (2016). Analysis of variables affecting performance in senior female volleyball World Championship 2014. International Journal of Performance Analysis in Sport, 16(1), 401-410.

Nejić, D., Stanković, D., Nejić, K., \& Stojadinović, Ž. (2016). Standardization of measuring tests for the jumping ability in volleyball. Facta Universitatis Series Physical Education and Sport, 193-200.

Nešić, G. (2006). Struktura takmičarske aktivnosti u odbojci (The structure of competitive activity in volleyball). PhD Thesis. Belgrade: Faculty of Sports and Physical Education, University of Belgrade. In Serbian.

Patsiaouras, A., Moustakidis, A., Charitonidis, K., \& Kokaridas, D. (2011). Technical skills leading in winning or losing volleyball matches during Beijing Olympic Games. Journal of Physical Education and Sport, $11(2), 39-42$.

Palao, J., Santos, J., \& Urena, A. (2004). Effect of the setter's position on the block in volleyball. International Journal of Volleyball Research, 6 (1), 29-32.

Tomić, D., \& Nemec, P. (2002). Odbojka u teoriji i praksi (Volleyball in theory and practice). Belgrade: Selfpublished by the Author. In Serbian

Viitasalo, J.T. (1990). Evaluation of physical performance characteristics in volleyball. International Volley Tech, 3 , 4-8.

Velasco, J. (1998). Pallavolo femminile, appunti sul corso di aggiornamento per allenatori (Women's volleyball, notes on the updated course for coaches). Bologna. In Italian

Velasco, J. (1999). Considerazioni sul metodo globale, appunti sul corso di aggiornamento per allenatori di Serie B (Global method considerations, notes on the updated course for Serie B coaches). Cattolica. In Italian

Železnak, J. (2004). Tendenciji razvitija klasičeskogo volejbola na savremenoj etape (Trends in the development of classic volleyball on the contemporary stage). Moscow: Theory and Practice of Physical Culture. In Russian

\section{RELACIJE TEHNIČKO-TAKTIČKIH ELEMENATA DIREKTNOG OSVAJANJA POENA U FUNKCIJI PLASMANA NA SVETSKOM ODBOJKAŠKOM PRVENSTVU ZA ŽENE 2018. GODINE}

Cilj rada je da se ispitaju relacije i razlike između odbojkaških reprezentacija, učesnica svetskog prvenstva 2018. godine u Japanu, podeljenih u tri kategorije po plasmanu (od 1. do 4. mesta, od 5. do 8. mesta i ostali), a prema elementima situacione efikasnosti.Za potrebe ovog rada korišćene su informacije iz zvaničnih izveštaja sa utakmica (p 2 izveštaj) koje se odnose na način osvajanja poena na utakmici, a analiza tih podataka je realizovana preko programa odbojkaški informacioni system (Voleyball Information System - VIS). Dobijeni podaci su analizirani u odnosu na kategoriju ekipe $i$ ishoda utakmice. Podaci su dobijeni primenom deskriptivnih $i$ komparativnih statističkih procedura. Uzorak u ovom istraživanju čine sve utakmice svetskog prvenstva u odbojci za žene odigrane u Japanu 2018. godine. Na osnovu konačnog plasmana reprezentacije su podeljene u tri grupe: 1) reprezentacije koje su stigle do 3. faze takmičenja (6 reprezentacija, plasman od 1. do 6. mesta); 2) reprezentantacije koje su takmičenje završile u 2. fazi (10 reprezentacija, plasman od 7. do 16. mesta); 3) reprezentacije koje su takmičenje završile u 1. fazi (8 reprezentacija, plasman od 17. do 24. mesta). Dobijeni rezultati ukazuju da ekipe imaju podjednako dobro izvođenje elementa bloka i servisa, ali statistički ne prikazuju značaj za konačan ishod, već kao pomoć pri realizaciji ukupnih elemenata odobjkaške igre na konačan ishod meča. Rezultati ovog istraživanja ističu i smeč kao ključni element za pozitivan krajnji ishod meča. Značajno je naglasiti da su greške protivnika faktor koji direktno zavisi od samog protivnika, ali $i$ na ukupan rezultat ekipa koje pobeđuju.

Ključne reči: kategorije, efikasnost, tehničko-taktički elementi, devojke, plasman. 